\title{
Expression of thyroid hormone regulator genes in the yolk sac membrane of the developing chicken embryo
}

\author{
Hanny Cho TOO ${ }^{1,2) *}$, Mitsuhiro SHIBATA ${ }^{1) *}$, Masato YAYOTA ${ }^{3)}$, Veerle M. DARRAS ${ }^{4)}$ and \\ Atsushi IWASAWA ${ }^{3)}$ \\ 1) United Graduate School of Agricultural Science, Gifu University, Gifu 501-1193, Japan \\ 2) Livestock Breeding and Veterinary Department, Ministry of Agriculture, Livestock and Irrigation, Naypyidaw, Myanmar \\ 3) Faculty of Applied Biological Sciences, Gifu University, Gifu 501-1193, Japan \\ 4) Laboratory of Comparative Endocrinology, Department of Biology, KU Leuven, Leuven B-3000, Belgium
}

\begin{abstract}
Thyroid hormones (THs) are essential for the correct development of nearly every structure in the body from the very early stages of development, yet the embryonic thyroid gland is not functional at these stages. To clarify the roles of the egg yolk as a source of THs, the TH content in the yolk and the expression of TH regulator genes in the yolk sac membrane were evaluated throughout the 21-day incubation period of chicken embryos. The yolk TH content (22.3 ng triiodothyronine and $654.7 \mathrm{ng}$ thyroxine per total yolk on day 4 of incubation) decreased almost linearly along with development. Realtime PCR revealed gene expression of transthyretin, a principal TH distributor in the chicken, and of a TH-inactivating iodothyronine deiodinase (DIO3), until the second week of incubation when the embryonic pituitary-thyroid axis is generally thought to start functioning. The TH-activating deiodinase (DIO2) and transmembrane transporter of thyroxine (SLCO1C1) genes were expressed in the last week of incubation, which coincided with a marked increase of circulating thyroxine and a reduction in the yolk sac weight. $D I O 1$, which can remove iodine from inactive THs, was expressed throughout the incubation period. It is assumed that the chicken yolk sac inactivates THs contained abundantly in the yolk and supplies the hormones to the developing embryo in appropriate concentrations until the second week of incubation, while THs may be activated in the yolk sac membrane in the last week of incubation. Additionally, the yolk sac could serve as a source of iodine for the embryo. Key words: Chicken, Iodothyronine deiodinase, Real-time PCR, Thyroid hormones, Yolk sac
\end{abstract}

(J. Reprod. Dev. 63: 463-472, 2017)

$\mathbf{T}$ he avian yolk sac, or more precisely the yolk sac membrane, is not only a "bag" enveloping the yolk containing all the nutrients necessary for normal embryo development, but also a metabolic organ that possesses a number of enzymes converting these nutrients to facilitate embryonic use [1-3]. The two main structural components of the yolk sac membrane are the epithelial cell layer and the capillary layer. The former is a monolayer of endodermal cells in direct contact with the yolk, whereas the latter is of mesodermal origin and consists of vascular endothelial cells and smooth muscle cells [4]. During incubation of the chicken egg, the yolk is absorbed by the epithelial cells and transported to the embryo via vascular cells [1].

Unlike in the case of mammals where the mother can supply nutrients to the fetus through the placenta, avian embryos have to nurture themselves with whatever is confined in their own eggshells. The yolk contains lipophilic hormones, such as steroids and thyroid hormones (THs), deposited by the mother when the egg was formed

Received: March 4, 2017

Accepted: May 31, 2017

Published online in J-STAGE: June 25, 2017

(C)2017 by the Society for Reproduction and Development

* HC Too and M Shibata contributed equally to this work.

Correspondence: A Iwasawa (e-mail: aiwa@gifu-u.ac.jp)

This is an open-access article distributed under the terms of the Creative Commons Attribution Non-Commercial No Derivatives (by-nc-nd) License. (CC-BY-NC-ND 4.0: https://creativecommons.org/licenses/by-nc-nd/4.0/) in the ovary [5]. The THs, 3,5,3'-triiodothyronine $\left(\mathrm{T}_{3}\right.$, potent $\left.\mathrm{TH}\right)$ and 3,5,3',5'-tetraiodothyronine $\left(\mathrm{T}_{4}\right.$ or thyroxine, less active $\left.\mathrm{TH}\right)$, are synthesized only in the thyroid gland. As in mammals, the THs are essential for the correct development of nearly every structure in the body in birds from the very early stages of development, yet the embryonic thyroid gland is not functional at these early stages $[6,7]$. It is therefore generally accepted that the yolk functions as a source of THs for the avian embryo by supplying them through the circulation before the embryo's own thyroid gland starts to function [5].

In all vertebrate species studied so far, more than $99 \%$ of THs in the circulation are transported by binding to distributor proteins [8]. In the case of adult birds, THs are distributed mainly by binding to transthyretin (TTR, previously called pre-albumin) and albumin (ALB) [9]. By applying the comprehensive serial analysis of gene expression approach to study the total yolk sac membrane in the last week of a 21-day incubation of chicken embryos, the expression of TTR and $A L B$ was shown [3], indicating a possibility of distribution of yolk THs to the embryo. Moreover, since THs do not readily cross the lipid bilayer membrane, the majority of THs are transported through the cell membrane via transmembrane transporters belonging to different transporter families, including members of the monocarboxylate transporter (MCT) and organic anion transporter (OATP) families [10]. Furthermore, the balance between activation and inactivation of THs within the cell is determined-largely independent of their circulating concentrations - by three types of 
iodothyronine deiodinases (DIO1, DIO2, and DIO3, also known as D1, D2, and D3) located in non-thyroidal tissues [11, 12]. Activation of THs occurs through the removal of iodine (deiodination) at the 5 '-position of $\mathrm{T}_{4}$ by DIO1 or DIO2, producing $\mathrm{T}_{3}$. Inactivation of $\mathrm{THs}$ occurs through the 5 -deiodination of $\mathrm{T}_{4}$ and $\mathrm{T}_{3}$ by DIO1 or DIO3, producing reverse $T_{3}\left(\mathrm{rT}_{3}\right)$ and diiodothyronine $\left(\mathrm{T}_{2}\right)$, respectively $[11,12]$. Gene expression of DIOs in yolk sac epithelial cells from embryonic day (E) 2 to E4 of chicken was revealed by microarray analysis [4], indicating a possibility of these enzymes regulating the balance of $\mathrm{T}_{3}$ and $\mathrm{T}_{4}$ distribution to the embryo or partially acting in the yolk sac membrane regardless of their respective concentrations in the yolk.

However, the fluctuation of these $\mathrm{TH}$ regulator molecules during the whole period of incubation of chicken embryos has never been characterized collectively. In the present study, we have analyzed the expression levels of the DIO1, DIO2, DIO3, TTR, and ALB genes in the same animal throughout the whole period of incubation to gain a broad-range view of the roles of the yolk sac membrane in processing and supplying THs to the developing embryo. In addition, the expression of SLC16A2 (MCT8 gene), SLC16A10 (MCT10 gene), and $S L C O 1 C 1$ (OATP1C1 gene), which are assumed to be responsible for transport of yolk THs in and out of the yolk sac membrane, was determined. The present results demonstrated the expression of DIO3 and TTR in the earlier period, DIO2 and SLCO1C1 in the later period, and $D I O I$ and $A L B$ in both periods of incubation, and the chronological atypical expression of SLC16A2 and SLC16A10.

\section{Materials and Methods}

\section{Animals and sampling}

Fertilized eggs from layer strain (Hy-Line) chicken were purchased from Japan Layer, Gifu, Japan. The eggs were incubated at $37.8^{\circ} \mathrm{C}$ and $70 \%$ relative humidity. The day of onset of incubation was labeled embryonic day 0 (E0). All the embryos (chicks) were pipping with their beaks outside the eggshell at the time of E21 sampling. The yolk sac membrane was sampled daily from E4 embryos to 3-dayold chicks (C3) (n=7-9). The membrane was rinsed thoroughly with sterile phosphate-buffered saline (PBS) with several changes to remove remaining yolk, put on a piece of filter paper to absorb excess PBS, weighed on an electronic balance, and then immediately frozen in liquid nitrogen and stored at $-85^{\circ} \mathrm{C}$ until RNA extraction. The yolk contents were collected every other day $(n=5)$, put into plastic tubes, weighed on an electronic balance, and stored at $-30^{\circ} \mathrm{C}$ for measuring the yolk TH concentrations. Blood was collected from the extraembryonic blood vessel on E10-E16, from the embryonic heart on E17-E20, and by quick decapitation on E21-C3 ( $n=7-9)$. E10 was the earliest day when we successfully collected blood that was not contaminated with other body fluids. Serum was prepared and stored at $-60^{\circ} \mathrm{C}$ until measurement of the $\mathrm{T}_{4}$ concentration. All animal manipulations were approved by the Animal Research and Welfare Committee at Gifu University.

\section{Quantification of $m R N A$ expression}

Total RNA was extracted from frozen yolk sac membranes using TRIzol reagent (Invitrogen, Carlsbad, CA, USA). RNase-free DNase I (gDNA Remover, TOYOBO, Osaka, Japan) was used to eliminate genomic DNA according to the manufacturer's instructions. Total RNA $(1 \mu \mathrm{g})$ was then reverse transcribed into first-strand cDNA using ReverTra Ace (TOYOBO) and a random primer (TOYOBO).

The mRNA levels were determined by real-time PCR, performed in an Mx3000P Real-Time PCR system (Agilent Technologies, Santa Clara, CA, USA) with the two-step standard cycling program for the Brilliant III Ultra-Fast SYBR Green QPCR Master Mix (Agilent). The volumes of reagents used for a single reaction were $10 \mu \mathrm{l}$ of QPCR Master Mix, $0.8 \mu \mathrm{l}$ of each $10 \mu \mathrm{M}$ forward and reverse primer, 7.4 $\mu \mathrm{l}$ of sterile water, and $1 \mu \mathrm{l}$ of template cDNA. The cycling program consisted of $3 \mathrm{~min}$ of initial denaturation at $95^{\circ} \mathrm{C}$, followed by 40 cycles of $5 \mathrm{sec}$ of denaturation at $95^{\circ} \mathrm{C}$ and $20 \mathrm{sec}$ of annealing and extension at $60^{\circ} \mathrm{C}$. The amplification program was followed by a dissociation curve analysis to detect any nonspecific amplification. Each experimental and standard sample was assayed in duplicates. Relative expression values were calculated according to the standard curve method, using the software installed in the Mx3000P System, with a serial dilution of pooled cDNAs as the standard. No-sample controls were included in the reactions to confirm the specificity of the reverse transcription and PCR amplification.

Using real-time PCR, we measured the expression of two housekeeping genes (GAPDH and RNA18S or $18 \mathrm{~S}$ ribosomal RNA) in the yolk sac membrane throughout development and found $R N A 18 S$ to be the most suitable since it did not show significant changes throughout development, with a difference of $12.4 \pm 7.5 \%$ (mean \pm standard deviation) between the mean expression values of each day.

The primers used for real-time PCR are listed in Table 1. The primers for DIO2, DIO3, TTR, SLC16A2, SLCO1C1, and RNA18S are previously reported sequences for Gallus gallus. The primers for $D I O 1, A L B$, and SLC16A10 were designed from G. gallus genomic sequences in the GenBank database using the online primer design software Primer3 [13]. The PCR-amplified products from these primers were sequenced by using the same primers; the determined sequences were $98-100 \%$ matched with the corresponding G. gallus sequences in the GenBank database.

We checked that the mRNAs quantified in the present study were virtually expressed in the yolk sac epithelial cells by scraping the cells off from the yolk sac membrane and analyzing the expression of these genes. The yolk sac membrane from E15-E20 eggs, thoroughly rinsed in sterile PBS as described above, was soaked in $0.05 \%$ trypsin- $0.02 \%$ EDTA solution (Wako Pure Chemical, Osaka, Japan) at $4^{\circ} \mathrm{C}$ while scraping the epithelial cells off gently with forceps under a dissecting microscope. Because some of the epithelial cells were still tightly adhered to the remaining membrane, we were unable to separate the vascular layer from the epithelial cell layer. The scraped cells were collected, rinsed three times in PBS by centrifugation $\left(150 \times g, 10 \mathrm{~min}, 4^{\circ} \mathrm{C}\right)$, and processed for RNA extraction and reverse transcription as described above. AmpliTaq Gold 360 DNA polymerase (Applied Biosystems, Foster City, CA, USA) was used for the PCR amplification according to the manufacturer's instructions. The cycling program consisted of $5 \mathrm{~min}$ of initial denaturation at $95^{\circ} \mathrm{C}$, followed by 35 cycles of $30 \mathrm{sec}$ of denaturation at $95^{\circ} \mathrm{C}, 30$ sec of annealing at $58^{\circ} \mathrm{C}$, and $30 \mathrm{sec}$ of extension at $72^{\circ} \mathrm{C}$. The PCR products were electrophoresed on a $10 \%$ polyacrylamide gel, stained with ethidium bromide, and photographed. 
Table 1. Primers used for PCR amplification

\begin{tabular}{|c|c|c|c|c|}
\hline Gene name & Accession No. & Primer sequence $\left(5^{\prime} \rightarrow 3^{\prime}\right)$ & Amplicon length (bp) & Reference \\
\hline \multirow[t]{2}{*}{ DIOI } & NM_001097614 & F: GCAGCACAATTTCTTCAGCA & 159 & Present study \\
\hline & & R: GTAATTCCAAGGCCCCACTC & & \\
\hline \multirow[t]{2}{*}{$\mathrm{DIO} 2$} & NM_204114 & F: TGTTTCTGAGCCGCTCCAA & 142 & [33] \\
\hline & & R: ACACTGGAGTTCGGAGCTTCTC & & \\
\hline \multirow[t]{2}{*}{$\mathrm{DIO}$} & NM_001122648 & F: CAGGAGGAGAAGGTGATGTACCA & 100 & [34] \\
\hline & & R: TCTGGAGCCGGGTTTTGTACT & & \\
\hline \multirow[t]{2}{*}{ TTR } & NM_205335 & F: AAGCTGGCAGGACTTTGCTA & 175 & {$[35]$} \\
\hline & & R: GCAGTGAACACCACATCAGC & & \\
\hline \multirow[t]{2}{*}{$A L B$} & NM_205261 & F: CCATGGTTGACAAGTGCTGC & 125 & Present study \\
\hline & & R: CTCACTGGCAACCGTGTCTT & & \\
\hline \multirow[t]{2}{*}{ SLC16A2 } & NM_001321737 & F: CAATCCTTCGGGATCATCTACA & 95 & [33] \\
\hline & & R: AGCCAACCATGCTGTTTTAA & & \\
\hline \multirow[t]{2}{*}{$S L C 16 A 10$} & NM_001321736 & F: CACCCATTGCAGGTTTGCTT & 201 & Present study \\
\hline & & R: ACACCAAAGTGCTTTCATTTTCCA & & \\
\hline \multirow[t]{2}{*}{ SLCO1C1 } & NM_001039097 & F: CATGGGACGATATCAGTATGAAAGA & 97 & [33] \\
\hline & & R: GGAGAGTGGAGTTTGGCTTTTCT & & \\
\hline \multirow[t]{2}{*}{ RNA18S } & AF173612 & F: TCAACTTTCGATGGTACTGTCTGTG & 106 & [35] \\
\hline & & R: CTTGGATGTGGTAGCCGTTTCT & & \\
\hline \multirow[t]{2}{*}{$\mathrm{CDH1}$} & NM_001039258 & F: GAAGACAGCCAAGGGCCTG & 224 & Present study \\
\hline & & R: GGGCCGTGTAGGATGTAACC & & \\
\hline \multirow[t]{2}{*}{ FOXA2 } & NM_204770 & F: CCTCGGTGAGCAACATGAAC & 129 & Present study \\
\hline & & R: CTGTGTTGGCGTAGGACATG & & \\
\hline \multirow[t]{2}{*}{ PDGFRA } & NM_204749 & F: CGCGTTATAAAGGAGGAGCTGT & 410 & Present study \\
\hline & & R: CGCGTTATAAAGGAGGAGCTGT & & \\
\hline
\end{tabular}

Above dashed line: primers used for both real-time and standard PCRs; Below dashed line: primers used only for standard PCR.

\section{Measurement of yolk THs by enzyme immunoassay}

THs were extracted from the frozen yolk using the methanol/ chloroform extraction procedure of Wilson and McNabb [7]. In brief, whole yolks ( $\mathrm{n}=5$ for each day) were diced with scissors and homogenized in a plastic syringe with an 18 -gauge needle by drawing and expelling the needle rod vigorously. The homogenized yolk (2 g) was transferred to a $50 \mathrm{ml}$ polypropylene centrifuge tube, and 8 $\mathrm{ml}$ of methanol containing $1 \mathrm{mM}$ propylthiouracil (Sigma-Aldrich, St. Louis, MO, USA) was added. The tube was shaken on a mixer $(150 \mathrm{rpm}, 10 \mathrm{~min})$ and then centrifuged $\left(1,700 \times \mathrm{g}, 10 \mathrm{~min}, 4^{\circ} \mathrm{C}\right)$, and the supernatant was decanted into another $50 \mathrm{ml}$ polypropylene tube. The precipitate was resuspended in $4 \mathrm{ml}$ of methanol, shaken for $10 \mathrm{~min}$, and centrifuged, and the supernatant was decanted into a third $50 \mathrm{ml}$ tube. The two separate supernatants each received 20 $\mathrm{ml}$ of chloroform and $2 \mathrm{ml}$ of $2 \mathrm{M}$ ammonium hydroxide and were shaken and centrifuged in the same way. The upper phase of the two tubes was collected and combined in another $50 \mathrm{ml}$ tube. The lower phase remaining in each tube was extracted again with ammonium hydroxide, and the upper phase from each was added to the $50 \mathrm{ml}$ tube. The sample was dried under a filtered air stream for 2 days at $15^{\circ} \mathrm{C}$. Once dried, the sample was resuspended in $4 \mathrm{ml}$ of ammonium hydroxide, vortexed well, and centrifuged, and the supernatant was decanted into a polypropylene tube. The whole extraction procedure was then repeated for this supernatant with $4 \mathrm{ml}$ of chloroform, and the upper phase was collected, dried, and resuspended in $300 \mu \mathrm{l}$ of $75 \%$ ethanol. The reconstituted extracts were stored at $-20^{\circ} \mathrm{C}$ until assayed for $\mathrm{TH}$ concentrations. The serum $\mathrm{T}_{4}$ concentration was measured directly without extraction or dilution.

$\mathrm{T}_{3}$ and $\mathrm{T}_{4}$ were measured using enzyme immunoassay kits (Immunospec, Canoga Park, CA, USA). According to the manufacturer's document, the cross-reactivity with related compounds other than $\mathrm{T}_{3}$ and $\mathrm{T}_{4}$ is less than $1.5 \%$. The linearity of the yolk extract and the serum sample to the standard curve was confirmed by measuring serially diluted samples with the assay buffer provided in the immunoassay kit. The intra- and inter-assay variations were $6.2-12.4 \%$ and $3.8-12.9 \%$, respectively.

To assess the recoveries of the above-described TH extraction procedure, fixed amounts of $\mathrm{T}_{3}(2.0 \mathrm{ng})$ and $\mathrm{T}_{4}(15.0 \mathrm{ng})$ were added to the thawed yolk before its homogenization. The yolk was processed as described above and the extracts were measured by enzyme immunoassay. The recoveries were $92.4 \pm 6.6 \%$ for $\mathrm{T}_{3}$ and $71.5 \pm 5.9 \%$ for $\mathrm{T}_{4}$ (mean \pm standard error of five separate trials), which were numerically better than the recoveries reported in the original paper ( $61 \%$ for $\mathrm{T}_{3}$ and $63 \%$ for $\left.\mathrm{T}_{4}\right)$ [7].

\section{Statistical analysis}

Data were expressed as the mean \pm standard error. Comparisons among groups were performed with one-way analysis of variance followed by the Tukey-Kramer multiple comparison test, using the JMP statistical package (ver. 10, SAS Institute Japan, Tokyo). A probability value of $\mathrm{P}<0.05$ was used throughout as the criterion to accept a significant difference of means. 


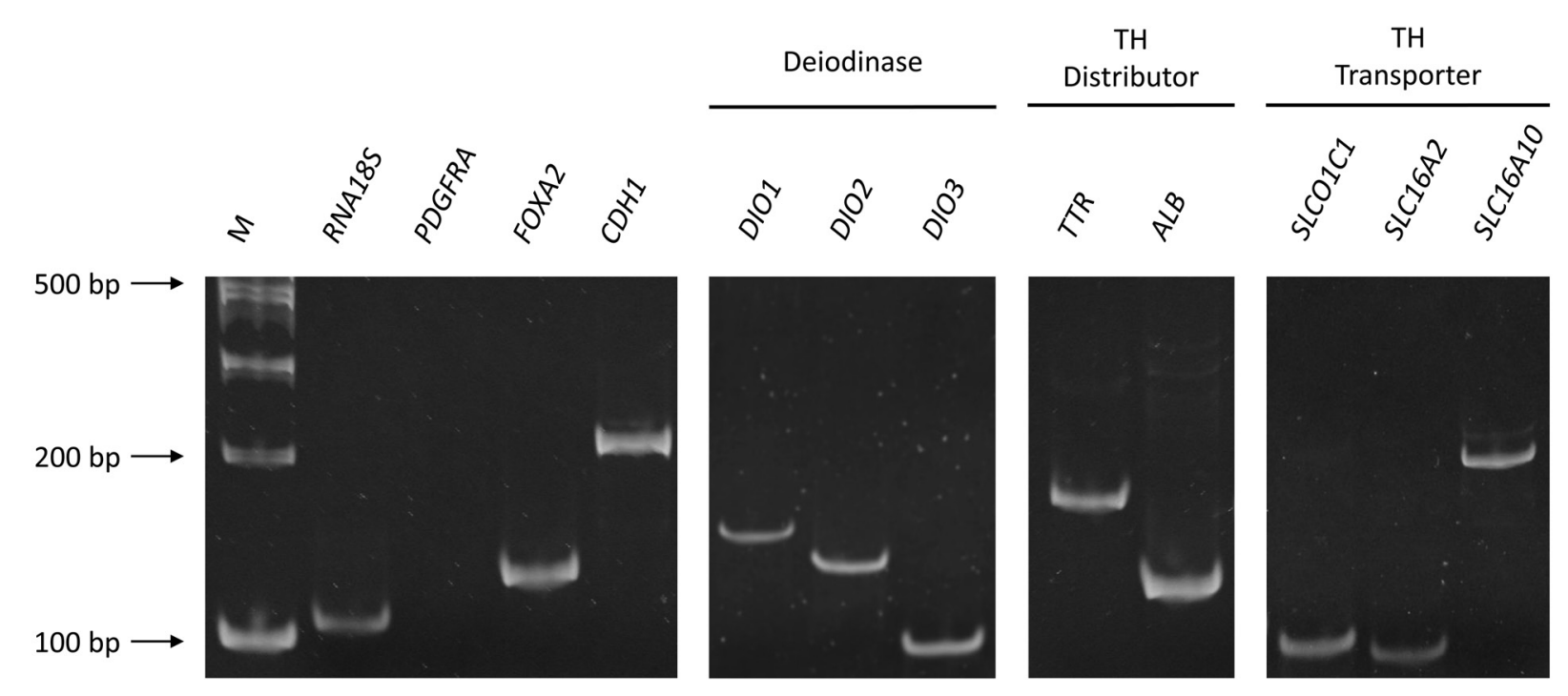

Fig. 1. Expression of thyroid hormone regulator genes in epithelial cells scraped off from the yolk sac membrane on embryonic day (E)18. $C D H 1$ and FOXA2 were used as markers of endoderm-derived cells; PDGFRA (410 bp, no band was detected) was used as a marker for mesoderm-derived cells. M: molecular weight marker. Electrophoretogram in a $10 \%$ polyacrylamide gel.

\section{Results}

First, we have confirmed by standard PCR that all the genes determined in the present study were expressed in the yolk sac epithelial cells, as shown in Fig. 1. Expression of FOXA2 (forkhead box protein A2) [14] and $C D H 1$ (E-cadherin) [4, 15], markers of endoderm-derived cells, was found in the epithelial cells scraped off from the yolk sac membrane, whereas PDGFRA (platelet-derived growth factor receptor alpha) [15], a marker of mesoderm-derived cells, was not amplified. In the rest of the yolk sac membrane (containing epithelial cell remnants and vascular layer; see Materials and Methods), however, PDGFRA was expressed as well as FOXA2 and $C D H 1$ (data not shown).

Then, we examined the concentration of circulating THs as well as their content in the yolk. As shown in Fig. 2, the serum $\mathrm{T}_{4}$ concentration was very low $(0.4-0.9 \mathrm{ng} / \mathrm{ml})$ from E10 to E14, but then increased gradually from E15 $(1.8 \mathrm{ng} / \mathrm{ml})$, peaked significantly on E20 $(36.6 \mathrm{ng} / \mathrm{ml})$, and then dropped on E21 to $9.7 \mathrm{ng} / \mathrm{ml}$, almost the same level as before the peak. The yolk weight (wet weight without yolk sac membrane) was $19.0 \mathrm{~g}$ on E4 and then gradually decreased along with development. As the embryos started hatching, the yolk weight decreased markedly from $6.19 \mathrm{~g}$ on E20 to $3.86 \mathrm{~g}$ on $\mathrm{C} 1$ and reached $0.66 \mathrm{~g}$ on $\mathrm{C} 2$. The total yolk $\mathrm{TH}$ content also showed significant decreases along with development; the yolk $\mathrm{T}_{3}$ content decreased from $22.3 \mathrm{ng}$ (on E4) to $2.2 \mathrm{ng}$ (on C2), and the yolk $\mathrm{T}_{4}$ content decreased from $654.7 \mathrm{ng}$ (on E4) to $50.0 \mathrm{ng}$ (on $\mathrm{C} 2$ ). The yolk TH concentrations did not change substantially during the incubation period (not shown in Fig. 2); $1.0 \mathrm{ng}\left(\mathrm{T}_{3}\right)$ and $30.4 \mathrm{ng}\left(\mathrm{T}_{4}\right)$ per gram yolk on $\mathrm{E} 4$, and $1.1 \pm 0.4 \mathrm{ng}\left(\mathrm{T}_{3}\right)$ and $27.9 \pm 4.2 \mathrm{ng}\left(\mathrm{T}_{4}\right)$ per gram yolk in the mean \pm standard deviation of all data from $\mathrm{E} 4$ to $\mathrm{C} 2$. The weight of the yolk sac membrane (wet weight without yolk) was $0.67 \mathrm{~g}$ on E4 and increased gradually, especially on and after E11 (1.79 g), and then peaked on E17 (4.67 g). The yolk sac membrane shrunk thereafter, reaching $0.68 \mathrm{~g}$ on $\mathrm{C} 3$, which was almost the same weight as on E4.

Real-time PCR was performed to examine whether DIOs are expressed in the yolk sac membrane. As shown in Fig. 3, all three $D I O$ s were expressed. DIOI was found to be highly expressed as early as E4 and increased about 2-fold to reach its maximum levels on E5-E6. It then decreased gradually and was only slightly detectable by the time of hatching. The cause of the transient decrease on E13 could not be determined. DIO3 expression was very low on E4 but increased suddenly ( $\sim 100,000$-fold $)$ to its maximum levels on E5-E6. It then decreased gradually and became very low again from E13 ( 1/3,000 of E6 level) onwards. In contrast to these two DIOs, $\mathrm{DIO} 2$ expression was very low between $\mathrm{E} 4$ and $\mathrm{E} 13$, increased from E14, and peaked at around the time of hatching (5.5-fold increase from E14 to E20).

Next, we examined the expression level of TH distributors in the yolk sac membrane. As shown in Fig. 4, TTR was highly expressed as early as E4 and then increased about 2-fold, showing a peak on E5 and another peak on E10 with slightly lower levels in between, the lowest being on E8 at almost the same level as on E4. It is noteworthy that TTR expression became very low from E13 onwards (1/80 of E10 level on E15), which resembled the expression profile of $D I O 3$. In contrast, $A L B$ expression showed peaks in both the earlier (on E10) and later (on E15; 1.7-fold higher than the E10 level) periods of development, and was very low from E19 onwards (1/60 of E15 level on E20). We again could not determine the reason for the transient decrease seen on E13.

Lastly, we measured the expression level of genes responsible for the transport of yolk THs. As shown in Fig. 5, TH transporter gene SLCO1C1 showed a mostly convex expression profile from E16 to E21. On the other hand, SLC16A2 and SLC16A10 both showed an atypical expression profile; $S L C 16 A 2$ was predominantly expressed on E4-E6, E13-E15, and C1 but had very low expression in between 


\section{$\rightarrow-$ Serum $T_{4} \rightarrow$ Total yolk $T_{4} \quad \rightarrow-$ Total yolk $T_{3}$}

Yolk weight $\quad \square$ Yolk sac weight

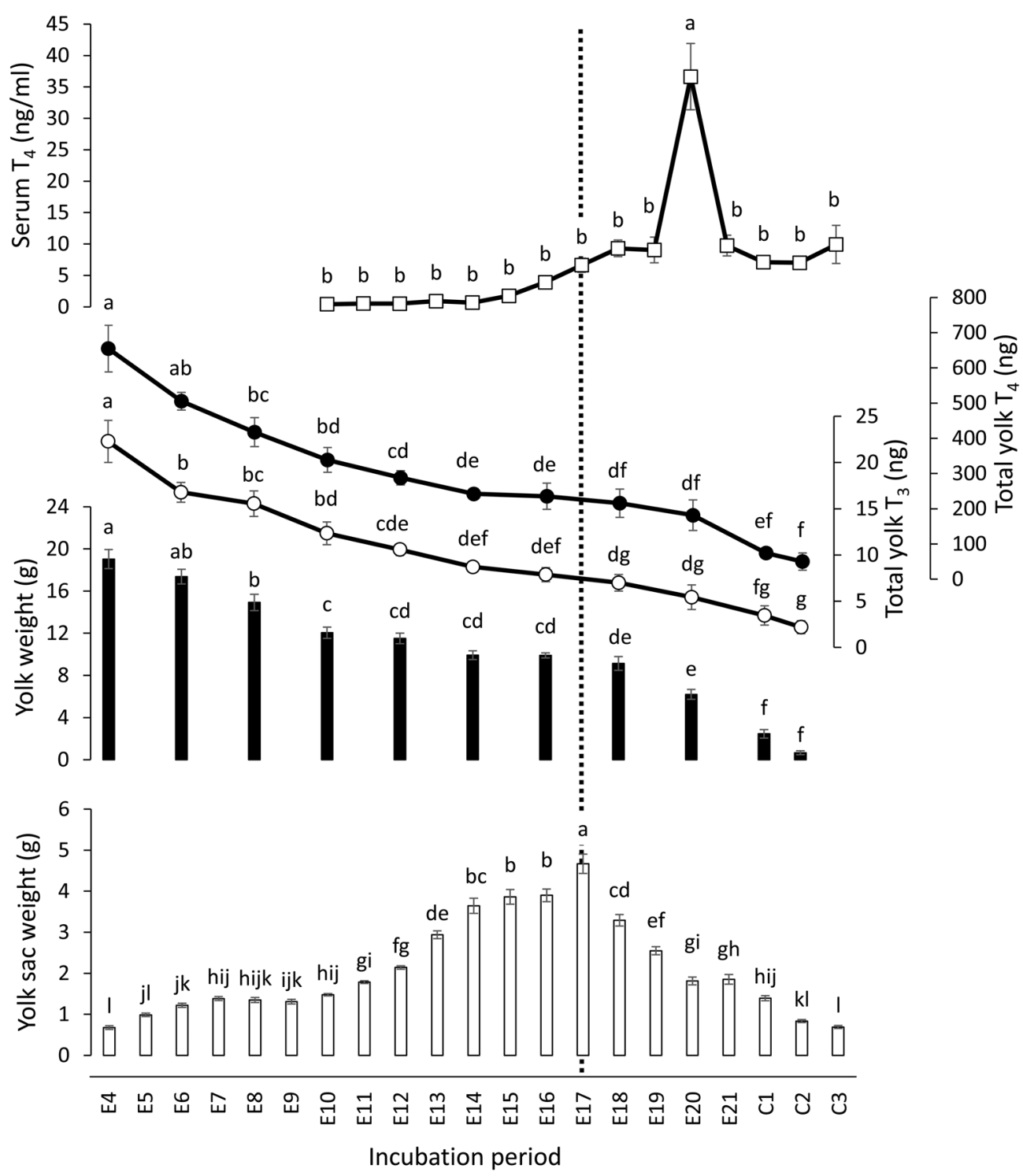

Fig. 2. Serum thyroxine $\left(T_{4}\right)$ concentration ( $m e a n \pm$ standard error, $n=7-9$ ), yolk weight ( $m$ mean \pm standard error, $\left.n=7-9\right)$, total triiodothyronine $\left(T_{3}\right)$ and $\mathrm{T}_{4}$ contents in the yolk (mean \pm standard error, $\mathrm{n}=5$ ), and wet weight of yolk sac membrane (mean \pm standard error, $\mathrm{n}=7-9$ ) during embryonic development of the chicken. Means without a common letter are significantly different within the same measurement category $(\mathrm{P}<0.05)$. E and $\mathrm{C}$ indicate the incubation day of the embryo and the day after hatching of the chick, respectively. The dotted line indicates the day when the weight of the yolk sac membrane showed its peak (E17).

these periods. SLC16A10 was predominantly expressed on E4-E9, E13-E14, and E19-C1. Taken together, the results indicate that the expression of the three membrane transporters seems to be independent during embryo development.

To summarize, expression of the TH regulator genes could be divided into two periods, approximately before and after E10-E13. DIO3 and TTR belong to the earlier period, whereas DIO2 and
SLCO1C1 belong to the later period. DIO1, ALB, SLC16A2, and $S L C 16 A 10$ were expressed in both these periods.

\section{Discussion}

The present study has given us two perceptions to gain clues to unraveling the functions of the avian yolk sac membrane in processing 


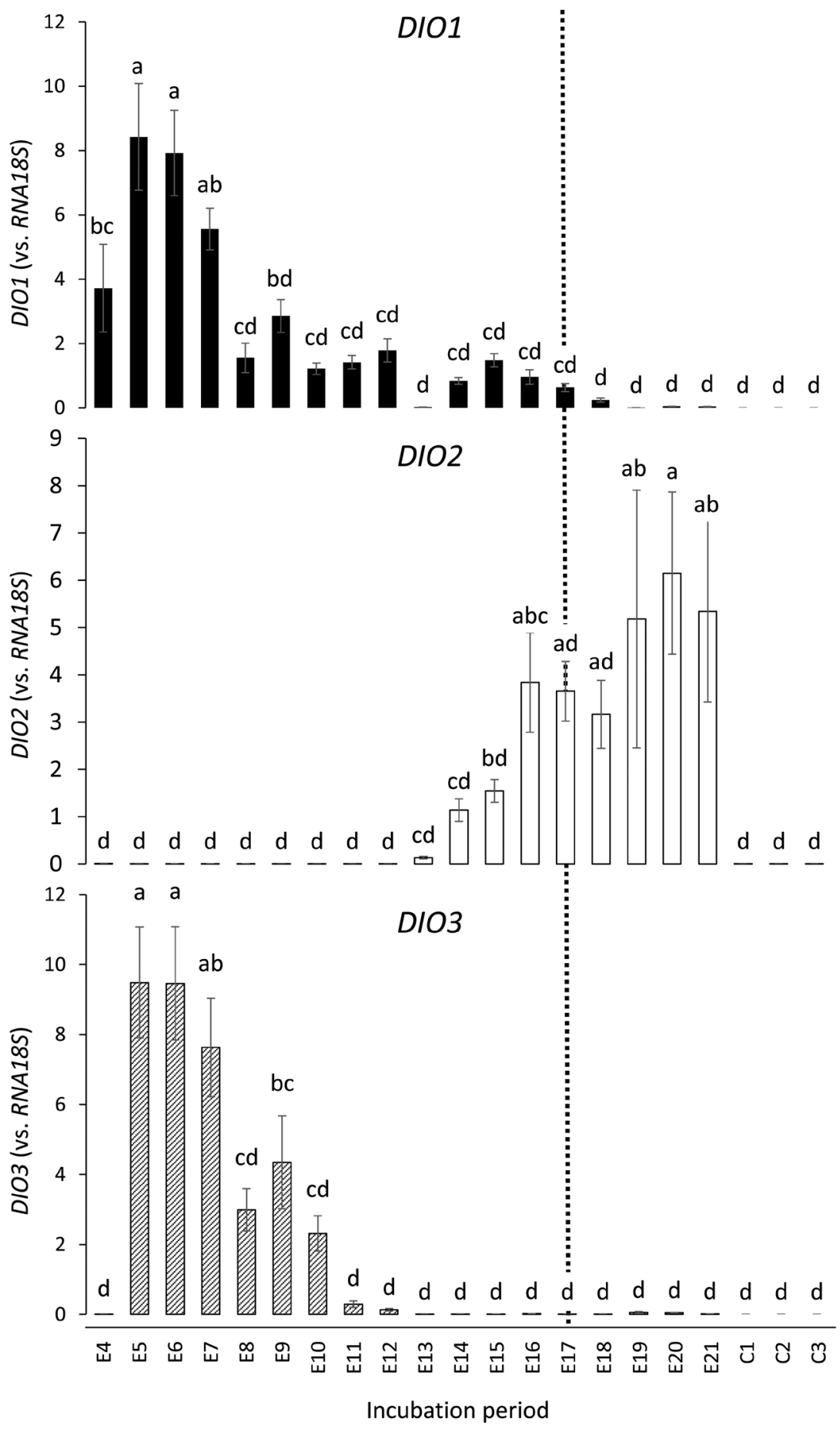

Fig. 3. Expression of iodothyronine deiodinase genes ( $D I O 1, D I O 2$, and $D I O 3)$ in the yolk sac membrane during embryonic development of the chicken, measured by real-time PCR. Each set of data represents the mean \pm standard error $(n=7-9)$. Means without a common letter are significantly different $(\mathrm{P}<0.05)$. Y-axes (expression vs. RNA18S) are expressed in arbitrary units. The dotted line indicates the day when the weight of the yolk sac membrane showed its peak (E17; Fig. 2).

and supplying yolk THs to the developing embryo. First, our results have confirmed previous observations that maternal THs in the yolk are available to the embryo [5]. Second, our study has shown that yolk THs could be metabolized before their distribution to the embryo or action in the yolk sac membrane.

Our results indicated that the yolk weight decreased significantly 


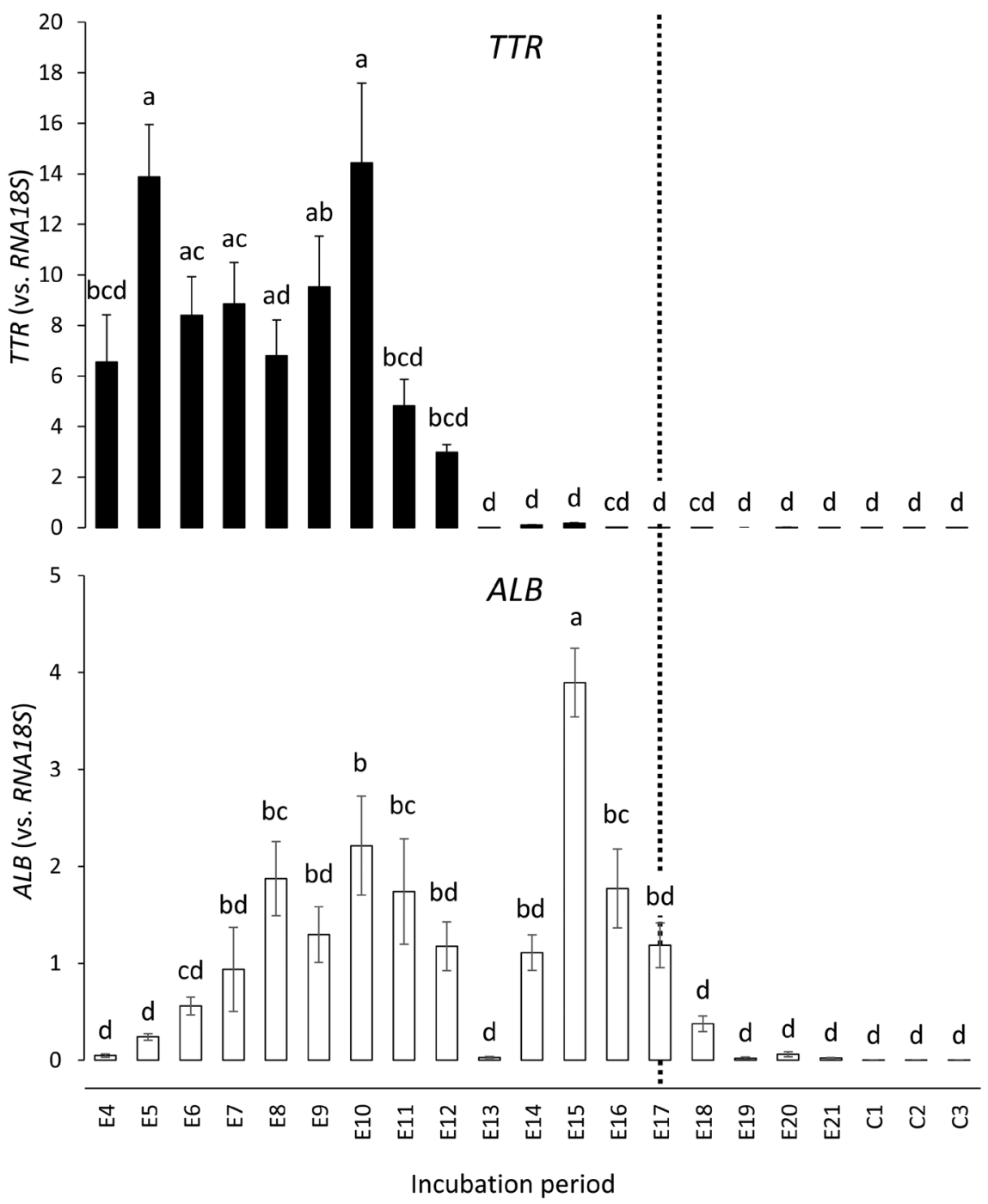

Fig. 4. Expression of $T T R$ and $A L B$ in the yolk sac membrane during chicken embryonic development, measured by real-time PCR. Each set of data represents the mean \pm standard error $(\mathrm{n}=7-9)$. Means without a common letter are significantly different $(\mathrm{P}<0.05)$. Y-axes (expression vs. RNA18S) are expressed in arbitrary units. The dotted line indicates the day when the weight of the yolk sac membrane showed its peak (E17; Fig. 2).

and almost linearly during the incubation period, as previously reported for chicken [16]. The total yolk TH content decreased in comparable tendency, and thus the yolk is likely to supply its components, including THs, to the developing embryo. THs in the circulation of adult chicken are mostly bound to TTR and ALB [9], and TTR synthesized in the visceral yolk sac of the rat is reported to be secreted toward the fetal circulation [17]. Therefore, the observed expression of TTR and $A L B$ in the chicken yolk sac membrane in the present study is supportive evidence that the yolk supplies THs to the embryo through the circulation.

It is generally accepted that the thyroid gland of the chicken embryo starts secreting THs somewhere between E10 and E12, under the control of the thyroid-stimulating hormone from the pituitary gland $[6,18]$. The present study showed that the expression of TTR, whose protein has high affinity for THs, was very low in the yolk sac membrane from E13 onwards. The role of the yolk sac as a source of circulating THs may thus weaken from around this time. Despite this, as clearly shown in Fig. 2, yolk THs were not yet depleted at this stage but went on to decrease further. A possibility is that ALB, whose gene expression increases between E14 and E18, contributes to TH distribution to the embryo in turn. Hilfer and Searls [19] reported that chicken embryos decapitated on E3 before the onset of pituitary function showed 100 -fold less $\mathrm{T}_{4}$ in the thyroid gland on E20, but only 2-fold less $\mathrm{T}_{4}$ in the blood, compared with the levels in the control embryo, and concluded that most of the circulating $\mathrm{T}_{4}$ was derived from the yolk. Their results seem to indicate that the yolk contains a sufficient amount of THs that can be supplied to the embryo even after the onset of thyroid function. The role, transporting route, and fate of yolk THs after the onset of thyroid function are thus intriguing and worthy of clarification. 


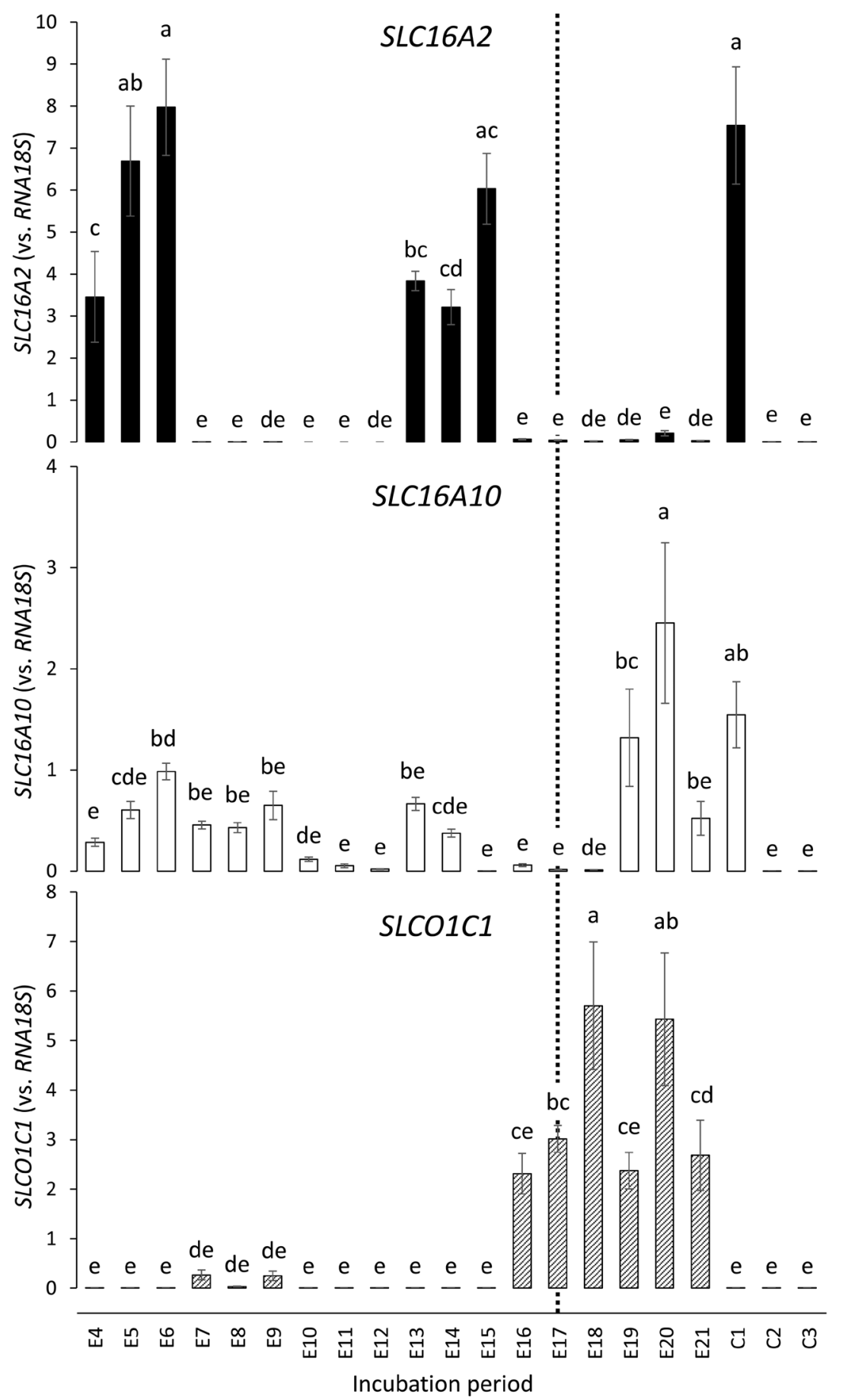

Fig. 5. Expression of transmembrane thyroid hormone transporters (SLC16A2, SLC16A10, and SLCO1C1) in the yolk sac membrane during chicken embryonic development, measured by real-time PCR. Each set of data represents the mean \pm standard error $(\mathrm{n}=7-9)$. Means without a common letter are significantly different $(\mathrm{P}<0.05)$. Y-axes (expression $v$ s. RNA18S) are expressed in arbitrary units. The dotted line indicates the day when the weight of the yolk sac membrane showed its peak (E17; Fig. 2).

Hitherto, experimental data in mammals have shown that maternal hyperthyroidism and hypothyroidism severely affect fetal brain development [20,21]. An appropriate amount of THs is therefore essential for the correct development of the embryo. The yolk TH concentrations revealed in the present study (1.0 ng $\mathrm{T}_{3}$ and 30.4 ng $\mathrm{T}_{4}$ per gram yolk on E4) are relatively high, being more or less 
comparable with the peak of circulating THs $\left(\mathrm{T}_{3}: \sim 2.6 \mathrm{ng} / \mathrm{ml}[22] ; \mathrm{T}_{4}\right.$ : $36.6 \mathrm{ng} / \mathrm{ml}$; Fig. 2) at the time of hatching of the chicks, when active thermoregulation is necessary. It is assumed that the TH-inactivating DIO3, whose gene was expressed in almost the same period as TTR and $A L B$ (E4-E12), could regulate the amount of TTR- and ALBborne $\mathrm{T}_{3}$, thereby preventing unfavorable premature $\mathrm{TH}$ signaling in the earlier embryo. Such role of DIO3 is well documented in the liver of embryonic chicken in the last half of incubation, where high expression of the enzyme in the liver keeps the embryonic plasma $\mathrm{T}_{3}$ level low, in spite of the gradually increasing plasma $\mathrm{T}_{4}$, until the last days of embryonic development. Plasma $T_{3}$ markedly increases to its peak level at the time of hatching, when hepatic DIO3 activity decreases by $98 \%$ from E17 to E21 [22, 23].

The expression of $\mathrm{DIO} 2$, the $\mathrm{TH}$-activating deiodinase gene, was high between E14 and E21. This period corresponded to the increase of circulating $\mathrm{T}_{4}$, beginning at around $\mathrm{E} 14$ and reaching its peak on E20. The expression of SLCO1C1, the gene of transmembrane transporter OATP1C1 with high preference for $\mathrm{T}_{4}[10]$, was also high at around this period. It may be responsible for transporting plasma $\mathrm{T}_{4}$ into the yolk sac epithelial cells. Taking these results together, we speculate that the increased $\mathrm{T}_{4}$ in the circulation is taken into the yolk sac epithelial cells and activated by DIO2 in situ to yield $\mathrm{T}_{3}$. A possible role of this $\mathrm{T}_{3}$ would be for the decrease in yolk sac weight starting from E17. The apoptotic gene cascade that causes tissue regression induced by $\mathrm{T}_{3}$ is well known in amphibians [24] and is also documented in Japanese quail testis [25]. In addition, a drastic decrease in the glycogen content of the yolk sac membrane occurs after E17 [3, 26], mainly to meet the embryonic demand for glucose as an energy source for hatching [3]. Although $\mathrm{T}_{3}$ is not known to induce direct activation of the genes encoding the glycogen breakdown enzymes, it is reported to facilitate glucose production in general; for example, by upregulating glucose 6-phosphatase [27, $28]$, an enzyme that enables glucose release into the circulation. We still do not have evidence to predict the roles of the transmembrane transporters MCT8 and MCT10, whose genes SLC16A2 and SLC16A10 were shown to be atypically expressed. Visualization of the three TH transporters OATP1C1, MCT8, and MCT10 (e.g., to see what transporters are localized on the apical or the basal surface of the cells) should provide further spatiotemporal insights into their specific functions and roles.

The DIO1 gene was expressed almost throughout the 21-day incubation period. DIO1 is a multifunctional enzyme that catalyzes both 5- and 5'-deiodination, but it prefers $\mathrm{rT}_{3}$ over $\mathrm{T}_{3}$ and $\mathrm{T}_{4}$ as the substrate [29]. The concentration of $\mathrm{rT}_{3}$ in the yolk is reported to be 7.7-fold higher than that in the serum of hens [30]. Thus, DIO1 in the yolk sac membrane could contribute to the recycling of iodine (by $5^{\prime}$-deiodination of $\mathrm{rT}_{3}$ to $\mathrm{T}_{2}$ ) that cannot be supplied from outside the egg, rather than to the activation of $\mathrm{T}_{4}$ to $\mathrm{T}_{3}$. It is estimated that $\sim 80 \%$ of the iodine in the yolk is transferred to the embryo during incubation [31]. In support of this, the expression of $S L C 5 A 8$, a transmembrane transporter of iodine, in the yolk sac membrane has been reported [32]. All these findings suggest that the egg yolk could be not only a source of THs but also an excellent source of iodine.

The present study suggests that the yolk sac membrane not only transfers yolk THs to the embryo but also activates and inactivates THs, thereby meeting the demands of the developing embryo and the yolk sac membrane. A part of the maternal THs contained abundantly in the yolk is probably inactivated by DIO3, preventing unfavorable premature $\mathrm{T}_{3}$ signaling. The resulting $\mathrm{rT}_{3}$ could easily be deiodinated further by DIO1, which can contribute to the recycling of iodine. In addition, the TH-activating enzyme DIO2 could increase the local $\mathrm{T}_{3}$ concentration in the yolk sac membrane in later stages, thereby regulating the function of this membrane toward the hatching stage. The present results warrant further detailed immunocytochemical and cell biological studies of the yolk sac membrane for elucidation of the subcellular mechanisms that regulate the processing and supply of THs from the yolk into the circulation.

\section{References}

1. Speake BK, Murray AM, Noble RC. Transport and transformations of yolk lipids during development of the avian embryo. Prog Lipid Res 1998; 37: 1-32. [Medline] [CrossRef]

2. Yadgary L, Yair R, Uni Z. The chick embryo yolk sac membrane expresses nutrient transporter and digestive enzyme genes. Poult Sci 2011; 90: 410-416. [Medline] [CrossRef]

3. Yadgary L, Uni Z. Yolk sac carbohydrate levels and gene expression of key gluconeogenic and glycogenic enzymes during chick embryonic development. Poult Sci 2012; 91 444-453. [Medline] [CrossRef]

4. Nakazawa F, Alev C, Jakt LM, Sheng G. Yolk sac endoderm is the major source of serum proteins and lipids and is involved in the regulation of vascular integrity in early chick development. Dev Dyn 2011; 240: 2002-2010. [Medline] [CrossRef]

5. McNabb FMA, Wilson CM. Thyroid hormone deposition in avian eggs and effects on embryonic development. Am Zool 1997; 37: 553-560. [CrossRef]

6. Prati M, Calvo R, Morreale G, Morreale de Escobar G. L-thyroxine and 3,5,3'-triiodothyronine concentrations in the chicken egg and in the embryo before and after the onset of thyroid function. Endocrinology 1992; 130: 2651-2659. [Medline] [CrossRef]

7. Wilson CM, McNabb FM. Maternal thyroid hormones in Japanese quail eggs and their influence on embryonic development. Gen Comp Endocrinol 1997; 107: 153-165. [Medline] [CrossRef]

8. Hulbert AJ. Thyroid hormones and their effects: a new perspective. Biol Rev Camb Philos Soc 2000; 75: 519-631. [Medline] [CrossRef]

9. McNabb FM. The hypothalamic-pituitary-thyroid (HPT) axis in birds and its role in bird development and reproduction. Crit Rev Toxicol 2007; 37: 163-193. [Medline] [CrossRef]

10. Visser WE, Friesema EC, Jansen J, Visser TJ. Thyroid hormone transport in and out of cells. Trends Endocrinol Metab 2008; 19: 50-56. [Medline] [CrossRef]

11. Schweizer U, Weitzel JM, Schomburg L. Think globally: act locally. New insights into the local regulation of thyroid hormone availability challenge long accepted dogmas. Mol Cell Endocrinol 2008; 289: 1-9. [Medline] [CrossRef]

12. Bianco AC, Salvatore D, Gereben B, Berry MJ, Larsen PR. Biochemistry, cellular and molecular biology, and physiological roles of the iodothyronine selenodeiodinases. Endocr Rev 2002; 23: 38-89. [Medline] [CrossRef]

13. Untergasser A, Cutcutache I, Koressaar T, Ye J, Faircloth BC, Remm M, Rozen SG. Primer3-new capabilities and interfaces. Nucleic Acids Res 2012; 40: e115-e127. [Medline] [CrossRef]

14. Goldman O, Han S, Hamou W, Jodon de Villeroche V, Uzan G, Lickert H, GouonEvans V. Endoderm generates endothelial cells during liver development. Stem Cell Rep 2014; 3: 556-565. [Medline] [CrossRef]

15. Tada S, Era T, Furusawa C, Sakurai H, Nishikawa S, Kinoshita M, Nakao K, Chiba T, Nishikawa S. Characterization of mesendoderm: a diverging point of the definitive endoderm and mesoderm in embryonic stem cell differentiation culture. Development 2005; 132: 4363-4374. [Medline] [CrossRef]

16. Romanoff AL. Chemistry of the extraembryonic membranes. In: Romanoff AL (ed.), Biochemistry of the avian embryo. New Yolk: John Wiley \& Sons; 1967: 143-175.

17. Thomas T, Southwell BR, Schreiber G, Jaworowski A. Plasma protein synthesis and secretion in the visceral yolk sac of the fetal rat: gene expression, protein synthesis and secretion. Placenta 1990; 11: 413-430. [Medline] [CrossRef]

18. De Groef B, Grommen SV, Darras VM. The chicken embryo as a model for developmental endocrinology: development of the thyrotropic, corticotropic, and somatotropic axes. Mol Cell Endocrinol 2008; 293: 17-24. [Medline] [CrossRef]

19. Hilfer SR, Searls RL. Differentiation of the thyroid in the hypophysectomized chick embryo. Dev Biol 1980; 79: 107-118. [Medline] [CrossRef]

20. Evans IM, Pickard MR, Sinha AK, Leonard AJ, Sampson DC, Ekins RP. Influence of 
maternal hyperthyroidism in the rat on the expression of neuronal and astrocytic cytoskeletal proteins in fetal brain. J Endocrinol 2002; 175: 597-604. [Medline] [CrossRef]

21. Lavado-Autric R, Ausó E, García-Velasco JV, Arufe MC, Escobar del Rey F, Berbel P, Morreale de Escobar G. Early maternal hypothyroxinemia alters histogenesis and cerebral cortex cytoarchitecture of the progeny. J Clin Invest 2003; 111: 1073-1082. [Medline] [CrossRef]

22. Darras VM, Visser TJ, Berghman LR, Kühn ER. Ontogeny of type I and type III deiodinase activities in embryonic and posthatch chicks: relationship with changes in plasma triiodothyronine and growth hormone levels. Comp Biochem Physiol Comp Physiol 1992; 103: 131-136. [Medline] [CrossRef]

23. De Groef B, Grommen SV, Darras VM. Hatching the cleidoic egg: the role of thyroid hormones. Front Endocrinol (Lausanne) 2013; 4: 63-10. [Medline]

24. Ishizuya-Oka A. Amphibian organ remodeling during metamorphosis: insight into thyroid hormone-induced apoptosis. Dev Growth Differ 2011; 53: 202-212. [Medline] [CrossRef]

25. Ikegami K, Atsumi Y, Yorinaga E, Ono H, Murayama I, Nakane Y, Ota W, Arai N, Tega A, Iigo M, Darras VM, Tsutsui K, Hayashi Y, Yoshida S, Yoshimura T. Low temperature-induced circulating triiodothyronine accelerates seasonal testicular regression. Endocrinology 2015; 156: 647-659. [Medline] [CrossRef]

26. García FJ, Pons A, Alemany M, Palou A. Tissue glycogen and lactate handling by the developing domestic fowl. Comp Biochem Physiol A 1986; 85: 155-159. [Medline] [CrossRef]

27. Feng X, Jiang Y, Meltzer P, Yen PM. Thyroid hormone regulation of hepatic genes in vivo detected by complementary DNA microarray. Mol Endocrinol 2000; 14: 947-955. [Medline] [CrossRef]

28. Mullur R, Liu YY, Brent GA. Thyroid hormone regulation of metabolism. Physiol Rev 2014; 94: 355-382. [Medline] [CrossRef]

29. Gereben B, Zeöld A, Dentice M, Salvatore D, Bianco AC. Activation and inactivation of thyroid hormone by deiodinases: local action with general consequences. Cell Mol Life Sci 2008; 65: 570-590. [Medline] [CrossRef]

30. Sechman A, Bobek S. Presence of iodothyronines in the yolk of the hens egg. Gen Comp Endocrinol 1988; 69: 99-105. [Medline] [CrossRef]

31. Daugeras-Bernard N, Lachiver F. Iodine supply to the thyroid gland in the developing chick embryo. Cell Differ 1980; 9: 31-39. [Medline] [CrossRef]

32. Yadgary L, Wong EA, Uni $\mathbf{Z}$. Temporal transcriptome analysis of the chicken embryo yolk sac. BMC Genomics 2014; 15: 690-705. [Medline] [CrossRef]

33. Van Herck SLJ, Geysens S, Delbaere J, Tylzanowski P, Darras VM. Expression profile and thyroid hormone responsiveness of transporters and deiodinases in early embryonic chicken brain development. Mol Cell Endocrinol 2012; 349: 289-297. [Medline] [CrossRef]

34. Crump D, Jagla MM, Chiu S, Kennedy SW. Detection of PBDE effects on mRNA expression in chicken (Gallus domesticus) neuronal cells using real-time RT-PCR and a new differential display method. Toxicol In Vitro 2008; 22: 1337-1343. [Medline] [CrossRef]

35. Roy TK, Iwasawa A, Shimizu Y, Kageyama K, Yoshizaki N. Ontogenic profile of gluconeogenic key enzyme gene expressions in embryonic chicken liver and muscle. Jpn Poult Sci 2013; 50: 381-387. [CrossRef] 